\title{
Facile Preparation of Porous Carbon Cathode to Eliminate Paracetamol in Aqueous Medium Using Electro-Fenton System
}

Thi Xuan Huong Le, Christophe Charmette, Mikhael Bechelany*, Marc Cretin*

Institut Européen des membranes, IEM UMR-5635, Université de Montpellier, ENSCM, CNRS, Place Eugène Bataillon 34095 Montpellier cedex 5 FRANCE.

* Corresponding authors: mikhael.bechelany@univ-montp2.fr and Marc.Cretin@univmontp2.fr

\begin{abstract}
Porous carbon cathode (PCF) was fabricated by thermal treatment at high temperature under a nitrogen gas flow mixed with $1 \%$ of oxygen. Scanning electron microscopy results revealed a homogenous porosity covered the carbon fibres. This property improved significantly the hydrophilicity that supported the oxygen reduction reaction (ORR) in electro-Fenton process as confirmed by contact angle measurements. In addition, an increase of 700 times of the surface area is observed after the thermal treatment. The crystalline average size of the new material was also ameliorated during thermal treatment as observed by X-ray diffraction pattern (XRD) due to the selective etching of amorphous carbon. Porous cathode exhibited also better electrochemical performances than raw carbon felt cathode as proved by cyclic voltammograms (CVs) because of the higher electroactive surface area. According to the Randles-Sevcik formula, the electroactive surface area of PCF was 10 times higher than raw CF. The concentration of $\mathrm{H}_{2} \mathrm{O}_{2}$ on PCF and raw CF was $24.6,7.9 \mathrm{mg} \mathrm{L}^{-1}$ respectively after $80 \mathrm{~min}$. The porous cathode was applied for removal of paracetamol (PCM) in acidic aqueous medium using an electro-Fenton process. Mineralization of PCM was followed by total organic carbon (TOC) measurements and
\end{abstract}


an improvement of $31 \%$ was observed compared to the non-modified cathode after $2 \mathrm{~h}$ of electrolysis. The porous carbon cathode kept its stability after 10 cycles.

KEYWORDS. Porous carbon felt, water treatment, electroactive surface area, mineralization, hydrogen peroxide production, electro-Fenton reaction

\section{GRAPHICAL ABSTRACT}

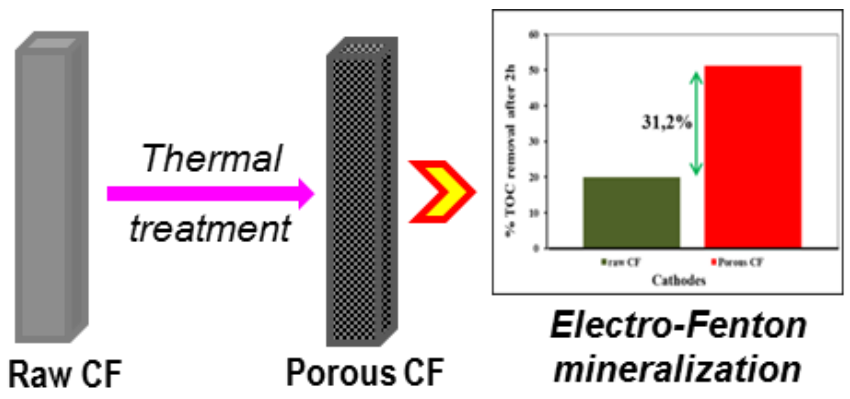

\section{Introduction}

Among Advanced Oxidation Processes (AOPs) technologies like ozonation [1], $\mathrm{UV} / \mathrm{H}_{2} \mathrm{O}_{2}$ [2] or photocatalytic oxidation [3], the electro-Fenton process has a high potential to ensure the mineralization (conversion into $\mathrm{CO}_{2}$ and $\mathrm{H}_{2} \mathrm{O}$ ) of organic pollutants and micropollutants. In the process, powerful oxidant hydroxyl radicals $(\cdot \mathrm{OH})$ are produced in an electrochemically assisted Fenton's reaction involving hydrogen peroxide $\left(\mathrm{H}_{2} \mathrm{O}_{2}\right)$ and ferrous iron, according to the following reaction: [4]

$$
\mathrm{Fe}^{2+}+\mathrm{H}_{2} \mathrm{O}_{2} \rightarrow \mathrm{Fe}^{3+}+{ }^{\circ} \mathrm{OH}+\mathrm{OH}^{-}
$$

Since this reaction takes place in acidic medium, it can alternatively be written as:

$$
\mathrm{Fe}^{2+}+\mathrm{H}_{2} \mathrm{O}_{2}+\mathrm{H}^{+} \rightarrow \mathrm{Fe}^{3+}+{ }^{\circ} \mathrm{OH}+\mathrm{H}_{2} \mathrm{O}
$$

$\mathrm{H}_{2} \mathrm{O}_{2}$ is formed via the two-electrons oxygen reduction reaction (ORR) at the cathode:

$$
\mathrm{O}_{2}+2 \mathrm{H}^{+}+2 \mathrm{e}^{-} \rightarrow \mathrm{H}_{2} \mathrm{O}_{2}
$$


Carbon-based materials are the best electrode used as a cathode in the electro-Fenton (EF) system. Different kinds of carbon based materials have been investigated: Carbon sponge cathode has been used in order to mineralize basic blue 3 (BB3) dye in water with efficiency of $50.8 \%$ higher than the carbon cathode after eight hours of electrolysis. $91.6 \%$ of TOC removal has been observed in the end of the process. [5] Polyacrylonitrile-based carbon fiber brush cathode has been as well investigated. It shows an efficiency of $86.2 \%$ of COD removal of phenol. The same cathode has been used for the mineralization of the complex real dyeing wastewater (Taiwan) with $70 \%$ of COD removal after 240 min of treatment. [6] Elisabetta et al. demonstrated that carbon felt $(\mathrm{CF})$ and reticulated vitreous carbon $(\mathrm{RVC})$ were more effective than graphite cathode in the $\mathrm{H}_{2} \mathrm{O}_{2}$ electrogeneration by electro-Fenton process [7].

In fact, the production of hydrogen peroxide is a crucial factor for the effective destruction of Persistent Organic Pollutants (POPs) by EF process. Oxygen gas is dissolved in the aqueous phase and sequentially transferred from the bulk to the cathodic surface, where it is reduced to hydrogen peroxide [8]. The efficiency of EF process was mainly limited by low mass transfer kinetics of hydrogen peroxide to the cathode due to the low solubility of oxygen or mislaying of $\mathrm{H}_{2} \mathrm{O}_{2}$ from its anodic oxidation via $\mathrm{HO}_{2} \bullet$ as an intermediate through the following reactions [9]:

$$
\begin{aligned}
& \mathrm{H}_{2} \mathrm{O}_{2} \rightarrow \mathrm{HO}_{2}^{\bullet}+\mathrm{H}^{+}+\mathrm{e}^{-} \\
& \mathrm{HO}_{2} \bullet \mathrm{O}_{2}+\mathrm{H}^{+}+\mathrm{e}^{-}
\end{aligned}
$$

To minimize problems, the process can then be optimized by using gas diffusion cathode [10] rotating cathode to optimize diffusion[11] or divided cell to avoid $\mathrm{H}_{2} \mathrm{O}_{2}$ oxidation at the anode[12]. Otherwise, there are also many studies focus on the modification of cathode materials to raise the electrogeneration of hydrogen peroxide though (i) the improvement of the electroactive surface area, and (ii) the hydrophilic property in order to accelerate the electron transfer of $\mathrm{O}_{2}$ reduction achieving higher mass transfer rate and to increase the reaction rate between $\mathrm{H}_{2} \mathrm{O}_{2}$ and the catalyst to decline the anodic oxidation. The modification of carbon felt 
for instance by ethanol/hydrazine hydrate shows a mineralization ratio on $\mathrm{p}$-nitrophenol (p-Np) of $51.4 \%$ after 120 min electrolysis, more than 2 times of the pristine one [13]. The modification of the same carbon felt by graphene demonstrated a 73.9\% TOC removal of Acid Orange 7 dye after $2 \mathrm{~h}$ treatment, which was $18.3 \%$ higher than on the raw carbon felt [14]. The deposition of carbon black and polytetrafluoroethylene (PTFE) on graphite felt could increase the in situ production of $\mathrm{H}_{2} \mathrm{O}_{2}$ by about 10.7 times [15], where the deposition of nitrogen functionalized carbon nanotube could increase the concentration of $\mathrm{H}_{2} \mathrm{O}_{2}$ by about 1.6 times in comparison to the non-modified electrodes. [16] Finally, the modification of the electrode by multi-walled carbon nanotubes/surfactant [17] or/and by polypyrrole/ anthraquinonedisulphonate composite film [18] attained also better results than the non-modified cathodes.

Paracetamol (N-(4-hydroxyphenyl) acetamide) is widely used in pharmaceutical field and has been known as a recalcitrant compound very difficult to remove completely [19]. This drug is detected in European sewage treatment plant (STP) with a concentration of $6 \mu \mathrm{g} / \mathrm{L}$ [20], up to $10 \mu \mathrm{g} / \mathrm{L}$ in water natural resource in USA [21] and over than $65 \mu \mathrm{g} / \mathrm{L}$ in the Tyne River, UK [22]. By increasing the usage of paracetamol yearly in the word, more amounts of pharmaceuticals enter the environment from manufacturing wastes which can produce toxic effects to aquatic organisms [23]. The Fenton process has been used as an efficient method to degrade the drug paracetamol from water. By the catalytic action of $\mathrm{Fe}^{2+}, \mathrm{Cu}^{2+}$, and UVA light on electrogenerated hydrogen peroxide, Sirés et al. had totally mineralized paracetamol after $6 \mathrm{~h}$ treatment, and some by-products formed during the electrolysis were detected like hydroquinone, p-benzoquinone, or short chain carboxylic acids [24]. In addition, acetaminophen was also removed by the combination between electro-Fenton and photoelectro-Fenton processes in a double cathodes electrochemical cell [25], by coupling of adsorption and photo-Fenton using nanozeolites and cobalt ferrite nanoparticles [26], by bio-electrochemical degradation in a microbial fuel cell-Fenton system [27], and finally by other methods relevant to the photoFenton process [28-31]. From that, the improvement of Fenton process to upgrade the treatment 
efficiency of recalcitrant pharmaceutical drugs is necessary as well as brings the enormous benefits for human living environment.

In this study, we prepared porous cathode from carbon felt by thermal treatment. This cathode was used to decompose PCM because that the improvement of the electroactive surface area after modification assisted the oxygen reduction reaction (ORR) to increase the $\mathrm{H}_{2} \mathrm{O}_{2}$ generation. Moreover, the porous morphology ameliorated remarkably the hydrophilicity of the raw carbon felt. Dissolved oxygen in the solution was moved quickly and easily to be reduced at the modified cathode. From that, the efficiency of the electro-Fenton process was improved and PCM mineralization was enhanced.

\section{Experimental}

\subsection{Materials}

The carbon felt was purchased from Johnson Matthey Co., Germany. Paracetamol (acetaminophen), sodium sulphate (anhydrous, $\geq 99 \%$ ) and iron (II) sulphate hepta-hydrate (99\%), were obtained from Sigma-Aldrich. Potassium hexacyanoferrate ( $\geq 99 \%)$ and potassium nitrate $(\geq 99 \%)$ were bought from Fluka. TOC standard of $1000 \mathrm{mg} / \mathrm{L}$ (Sigma-Aldrich Co) and sodium hydrogen carbonate ( $\geq .99 .5 \%$, ACS, Karlsruhe) were used for calibration. Potassium titanium (IV) oxalate (99.99\%, Alfa Aesar), and potassium permanganate (> $99 \%$ ), acid sulfuric (95-97\%), standard hydrogen peroxide solution ( $\geq 30 \% \mathrm{w} / \mathrm{w})$ from Sigma-Aldrich were used for the hydrogen peroxide accumulation determination with time.

\subsection{Preparation of porous carbon felt}

The commercial carbon felt with a dimension of $5.0 \mathrm{~cm} \times 1.0 \mathrm{~cm} \times 1.27 \mathrm{~cm}$ was first cleaned in an ultrasonic bath with acetone for $2 \mathrm{~h}$ to remove adsorbed contaminations, followed by thorough rinse with deionized water and dried at $60^{\circ} \mathrm{C}$ for $24 \mathrm{~h}$. This pretreated carbon felt was denoted as raw CF. After that, these carbonaceous samples were thermal treated in a tubular 
furnace (Vecstar Ltd), feeding by a mixture $\mathrm{N}_{2} / \mathrm{O}_{2}$ with $1 \%$ of oxygen. To obtain the optimal condition, experiments were performed under various parameters such as different treatment temperatures and times through keeping constantly the income gas flow at $200 \mathrm{~mL} / \mathrm{min}$. The sample at the best state was noted as Porous Carbon Felt (PCF).

\subsection{Material Characterization}

Chemical and structural characterizations have been performed using a scanning electron microscopy (SEM, Hitachi S-4800), a homemade contact angle meter, and a X-ray diffraction (PANAlytical Xpert-PRO diffractometer equipped with a X'celerator detector using Ni-filtered $\mathrm{Cu}$-radiation). The crystallite size was obtained from the X-ray diffraction pattern using of the Scherrer's formula [32].

$$
D=\frac{k \lambda}{\beta \cos \theta}
$$

Where $\mathrm{D}$ is the grain size $(\AA), \mathrm{k}$ is a constant equal to $0.94, \beta$ is the full width at half maximum (FWHM) (radian) and $\lambda(\AA)$ is the wavelength of the X-rays.

The $\mathrm{N}_{2}$ sorption-desorption isotherms were measured with a Micromeritrics ASAP 2010 equipment (outgassing conditions: $200^{\circ} \mathrm{C}-12 \mathrm{~h}$ ).

Electrochemical characterization was investigated relying on cyclic voltammograms (CVs). Experiments were conducted in solution of $10 \mathrm{mM} \mathrm{K}_{3}\left[\mathrm{Fe}(\mathrm{CN})_{6}\right]$ and $1.0 \mathrm{M} \mathrm{KCl}$ by using the $\mu 3$ AUT70466 Autolab system (Eco Chemie BV, Netherlands) and Bio-Logic SP-150 in a three-electrodes cell including a working electrode (modified and unmodified CF), a counter electrode ( $\mathrm{Pt}$ foil), and a reference electrode (Saturated Calomel Electrode, SCE). The electroactive surface area of cathodes was calculated according to the Randles-Sevcik formula $[33,34]$.

$$
I p=2.69 \times 10^{5} \times A D^{1 / 2} n^{3 / 2} \gamma^{1 / 2} C
$$

Where $\mathrm{n}$ is the number of electrons participating in the redox reaction, $\mathrm{A}$ is the area of the electrode $\left(\mathrm{cm}^{2}\right), \mathrm{D}$ is the diffusion coefficient of the molecule in solution $\left(\mathrm{cm}^{2} \cdot \mathrm{s}^{-1}\right), \mathrm{C}$ is the 
concentration of the probe molecule in the bulk solution $\left(\mathrm{mol} \mathrm{cm}{ }^{-3}\right)$, and $\gamma$ is the scan rate of the potential perturbation $\left(\mathrm{V} \mathrm{s}^{-1}\right)$.

\subsection{Electrogeneration of hydrogen peroxide}

Hydrogen peroxide concentrations were determined by spectrophotometry using the potassium titanium (IV) oxalate as a colored indicator. The absorbance of the yellow pertitanic acid complex between hydrogen peroxide and potassium titanium oxalate in acid solution was measured by a Spectrophotometer Jenway 6300 (Barioworld Scientific Ltd, Dunmow UK) at $\lambda=$ $400 \mathrm{~nm}$ through a $10 \mathrm{~mm}$ quartz cuvette. The calibration curve was contributed from standard hydrogen peroxide solution which was titrated by potassium permanganate solution $(0.1 \mathrm{~N})$. Electrogeneration of $\mathrm{H}_{2} \mathrm{O}_{2}$ was carried out in the undivided two-electrodes cell with platinum foil as anode and carbon felt as cathode containing $30 \mathrm{~mL}$ solution of $\mathrm{Na}_{2} \mathrm{SO}_{4}(50 \mathrm{mM}, \mathrm{pH}=3)$ under saturating of oxygen.

\subsection{Mineralization of paracetamol by the EF process}

The electro-Fenton treatment of paracetamol (PCM) aqueous solution was carried out in a $75 \mathrm{~mL}$ undivided two-electrodes cell using a stabilized alimentation (Lambda Electronique, USA) to control the applied current. The prepared cathode $\left(2 \mathrm{~cm}^{2}\right)$ was used as working electrode and a platinum foil as counter electrode. The distance between the working electrode and the counter electrode was $3 \mathrm{~cm}$. The $30 \mathrm{~mL}$ aqueous solution of PCM $(0.1 \mathrm{mM})$ and $\mathrm{Na}_{2} \mathrm{SO}_{4}$ $(50 \mathrm{mM})$ as supporting electrolyte and $\mathrm{FeSO}_{4} \cdot 7 \mathrm{H}_{2} \mathrm{O}(0.2 \mathrm{mM})$ as the catalyst were prepared by adjusting $\mathrm{pH}$ at 3. Prior to the electrolysis, oxygen was bubbled to saturate the solutions which were stirred magnetically at $800 \mathrm{rpm}$. The total organic carbon (TOC) of the initial and treated samples was measured with a TOC-L CSH/CSN Shimadzu (Japan) analyzer. Calibration curves for total carbon (TC) and inorganic carbon (IC) analysis were built up by automatic dilution of standards solutions of TOC (potassium hydrogenophtalate) and IC (sodium hydrogen carbonate). 


\section{Results and discussion}

\subsection{Chemical and structural characterizations of porous carbon cathode}

Figure 1a and $1 \mathrm{~b}$ illustrated the SEM images of the raw Carbon Felt $(\mathrm{CF})$ and Porous CF (PCF) obtained by thermal treatment at $1000^{\circ} \mathrm{C}$ for $1 \mathrm{~h}$ under a nitrogen flow mixing with $1 \%$ oxygen. It was observed that the morphology of raw CF was very smooth without any porous structure compared to PCF. Therefore, CF owned a very low surface area around $0.09 \mathrm{~m}^{2} / \mathrm{g}$ (Table 1) attributed to a non-porous system. In contrast, the surface of PCF was very rough and filled up by many holes. As the result of thermal treatment by gas flow containing $1 \%$ oxygen under high temperature, the upgraded surface area was identified to be $63.88 \mathrm{~m}^{2} / \mathrm{g}$ and the pore volume is calculated to be $0.0707 \mathrm{~cm}^{3} / \mathrm{g}$ (Table 1) which was 700 times higher than the raw $\mathrm{CF}$. The contact angle of the modified sample was $0^{\circ}$ instead of $89.9^{\circ}$ on the bare one (Figure $1 \mathrm{c}, \mathrm{d}$ ) because of the fast water droplets absorption by this porous structure. This higher surface hydrophilicity was helpful to enhance the production of hydrogen peroxide from the dissolved oxygen adsorbed at the surface of cathode in electro-Fenton process [35, 36]. In addition, the increase of the surface area could promote the electron transport and the mass transfer between the cathode and the electrolyte, which was proved by the enhancement of the electrocatalytic behavior as showed later with cyclic voltammograms (CVs) (Figure 1f). 

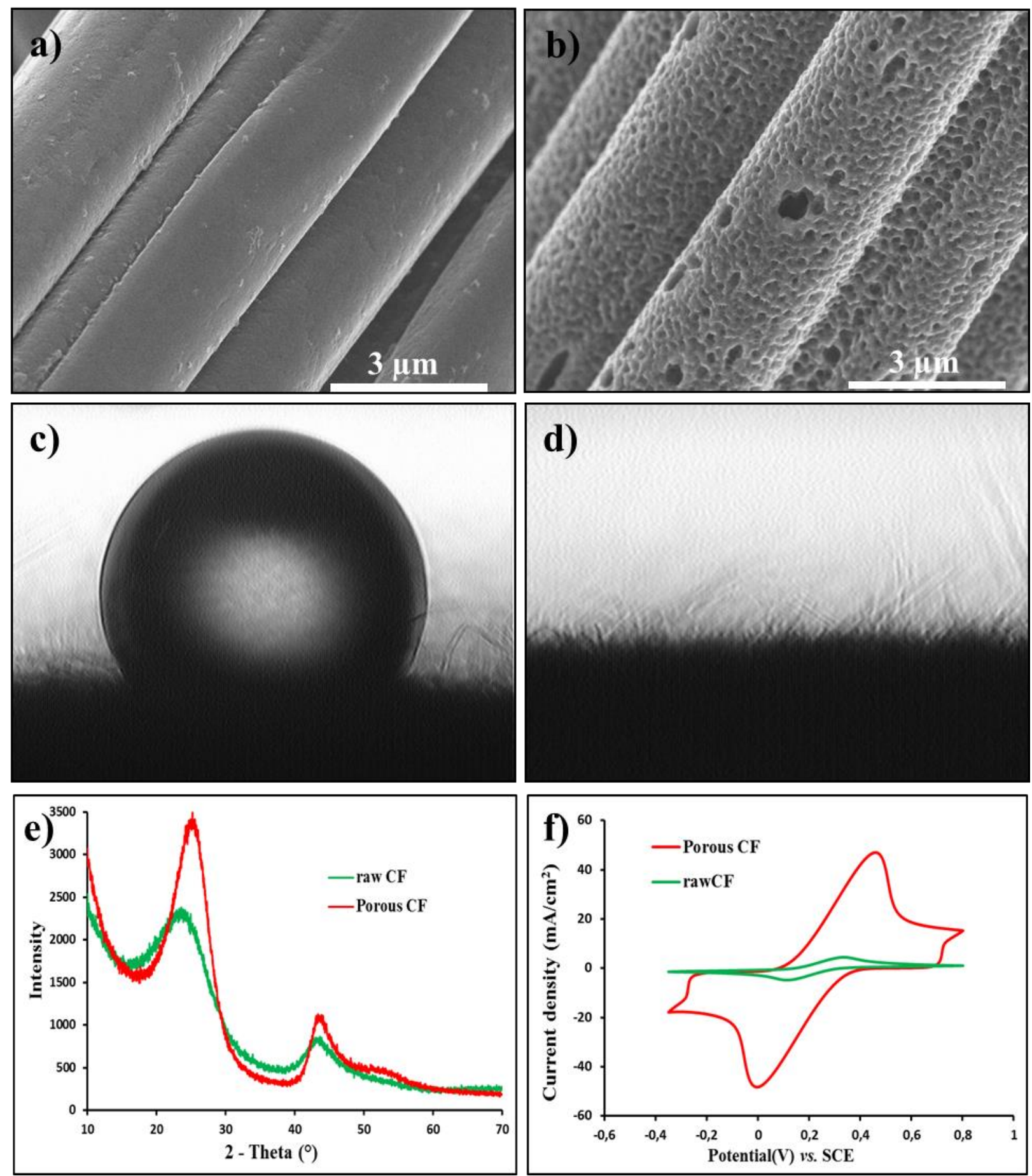

Figure 1. SEM images of (a) raw carbon felt (raw CF) and (b) Porous carbon felt (PCF) after thermal treatment at $1000^{\circ} \mathrm{C}$ for $1 \mathrm{~h}$ under nitrogen flow mixing with $1 \%$ oxygen. Shapes of water droplets formed on (c) raw $\mathrm{CF}$ and (d) Porous carbon felt. (e) X-ray diffraction patterns of raw $\mathrm{CF}$ and Porous $\mathrm{CF}$, and (f) Cyclic voltammograms (CVs) in potassium hexacyanoferrate solution at scan rate $7 \mathrm{mV} / \mathrm{s}$ of raw $\mathrm{CF}$ and Porous $\mathrm{CF}$. 
Table 1. Surface area and porosity of carbon felt for different thermal treatments under a nitrogen gas flow mixed with $1 \%$ of oxygen.

\begin{tabular}{|c|c|c|c|c|c|}
\hline & raw $\mathrm{CF}$ & $\mathrm{CF}-600^{\circ} \mathrm{C} / 1 \mathrm{~h}$ & $\mathrm{CF}-800^{\circ} \mathrm{C} / 1 \mathrm{~h}$ & $\mathrm{CF}-1000^{\circ} \mathrm{C} / 1 \mathrm{~h}$ & $\mathrm{CF}-1000^{0} \mathrm{C} / 3 \mathrm{~h}$ \\
\hline $\begin{array}{c}\text { Surface } \\
\text { Area }\left(\mathrm{m}^{2} / \mathrm{g}\right)\end{array}$ & 0.09 & 1.37 & 12.11 & 63.88 & 2.91 \\
\hline $\begin{array}{c}\text { Pore } \\
\text { Volume } \\
\left(\mathrm{cm}^{3} / \mathrm{g}\right)\end{array}$ & - & 0.0016 & 0.0086 & 0.0707 & 0.0041 \\
\hline $\begin{array}{c}\text { Pore Size } \\
(\AA)\end{array}$ & - & 22.1 & 28.9 & 32.5 & 42.2 \\
\hline
\end{tabular}

The crystalline average size of the material was also improved during the thermal treatment. The crystallite size obtained from the X-ray diffraction pattern (Figure 1e) was calculated by Scherrer's formula. For PCF and raw CF, values are $13.5 \AA$ and $12.7 \AA$ respectively (Table 2). This increase of the crystal size average is related to the fact that at high temperature $\left(1000^{\circ} \mathrm{C}\right)$, the amorphous and turbostratic carbon would be oxidized first by the reaction with oxygen in the oven and the more crystallite (graphitic) carbon remained which would increase the average of the crystalline size. In fact, owing to much more defects existing in the amorphous carbon, oxidation would be more reactive toward the amorphous carbon and turbostatic carbon than the graphitic carbon. This selective etching due to the fact that amorphous carbon can be etched away more easily (faster oxidation reaction), will induce the increase in the surface area and the appearance of the porosity in the PCF [37].

To investigate the effect of thermal treatment on the electrochemical activity of cathodes, cyclic voltammograms were shown in Figure 1f. It could be seen that PCF resulted in larger current response toward $\left[\mathrm{Fe}(\mathrm{CN})_{6}\right]^{3-/ 4-}$ when compared to raw $\mathrm{CF}$ in the scan range between $0.8 \mathrm{~V}$ and $-0.35 \mathrm{~V} / \mathrm{ECS}$. The porous surface as well as the improved hydrophilicity enhanced the electron-transfer efficiency, leading to the expansion of electroactive surface area on PCF. Electroactive surface area was calculated from the Randles-Sevcik formula and was 586.44 $\mathrm{cm}^{2} / \mathrm{g}$ for PCF, 10 times higher than raw $\mathrm{CF}\left(62.16 \mathrm{~cm}^{2} / \mathrm{g}\right)$. 
Table 2. Crystallite size and electroactive surface area of carbon felt for different thermal treatments under a nitrogen gas flow mixed with $1 \%$ of oxygen.

\begin{tabular}{|c|c|c|c|c|c|c|c|}
\hline & $\begin{array}{l}\text { raw } \\
\text { CF }\end{array}$ & $\begin{array}{l}\text { CF- } \\
600^{0} \mathrm{C} / 1 \mathrm{~h}\end{array}$ & $\begin{array}{l}\text { CF- } \\
800^{0} \mathrm{C} / 1 \mathrm{~h}\end{array}$ & $\begin{array}{l}\text { CF- } \\
1000^{0} \mathrm{C} / 1 \mathrm{~h}\end{array}$ & $\begin{array}{l}\mathrm{CF}- \\
1000^{0} \mathrm{C} / 30\end{array}$ & $\begin{array}{l}\mathrm{CF}- \\
1000^{0} \mathrm{C} / 2 \mathrm{~h}\end{array}$ & $\begin{array}{l}\text { CF- } \\
1000^{0} \mathrm{C} / 3 \mathrm{~h}\end{array}$ \\
\hline $\begin{array}{l}\text { Crystallite } \\
\text { size (ঐ) }\end{array}$ & 12.7 & 13.0 & 13.2 & 13.5 & 13.4 & 12.9 & 12.4 \\
\hline $\begin{array}{l}\text { Electroactive } \\
\text { surface area } \\
\left(\mathrm{cm}^{2} / \mathrm{g}\right)\end{array}$ & 62.16 & 461.64 & 524.03 & 586.44 & 536.50 & 486.60 & 349.35 \\
\hline
\end{tabular}

\subsection{Effect of the thermal treatment temperature}
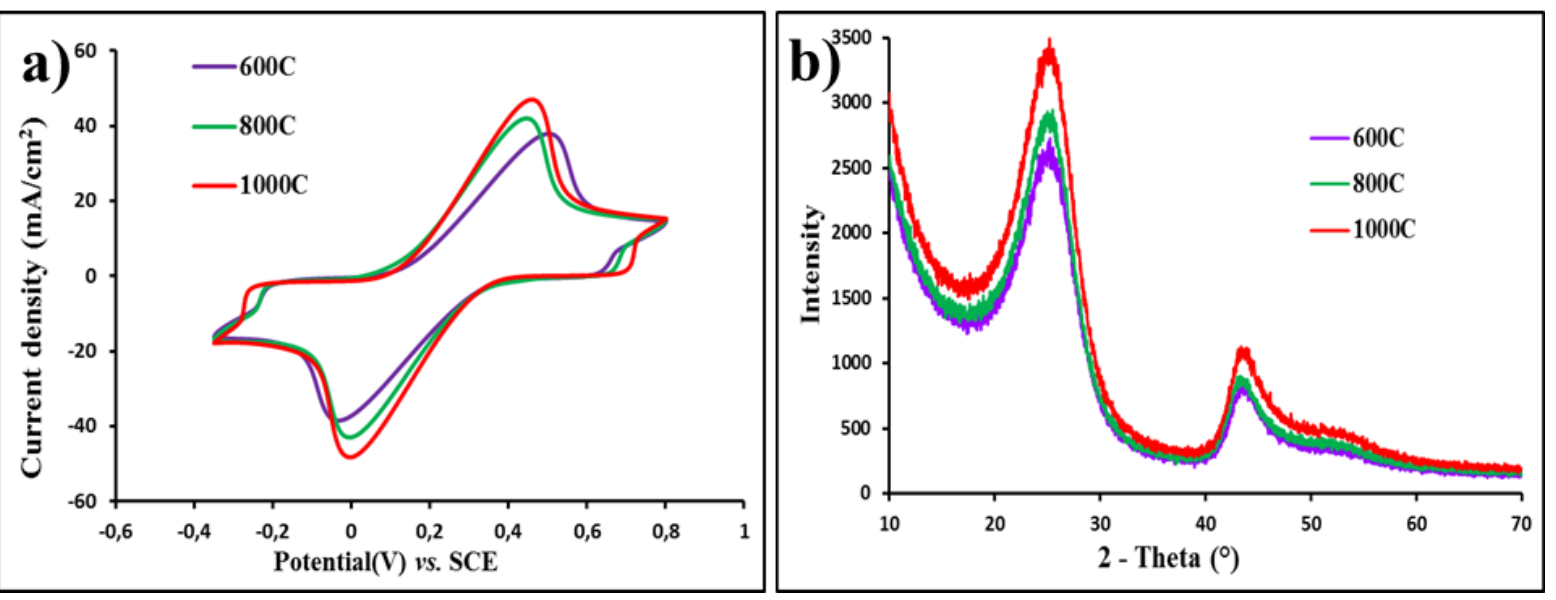

Figure 2. (a) Cyclic voltammograms (CVs) in potassium hexacyanoferrate solution at scan rate 7 $\mathrm{mV} / \mathrm{s}$, and (b) X-ray diffraction patterns of electrodes treated at different thermal temperatures in 1h under nitrogen flow mixing with $1 \%$ oxygen.

Figure 2 presented cyclic voltammograms and XRD patterns at different temperatures of treatment. The peak current of the redox probe $\left[\mathrm{Fe}(\mathrm{CN})_{6}\right]^{3-} /\left[\mathrm{Fe}(\mathrm{CN})_{6}\right]^{4-}$ increased as the temperature climbed from $600^{\circ} \mathrm{C}$ up to $1000^{\circ} \mathrm{C}$. The average crystallite size increased with the increase of calcination temperature: 13.0, 13.2 and $13.5(\AA)$ for 600,800 and $1000^{\circ} \mathrm{C}$ respectively. Increasing the temperature will increase the etching rate of amorphous carbon (Table 1,2). Increasing the thermal annealing under oxygen would create more pores covering 
the whole of the carbon fibers [38]. This porous structure would increase the available surface area for electrochemical reaction, as observed in other studies relevant to thermal treatment [39].

\subsection{Effect of thermal treatment time}
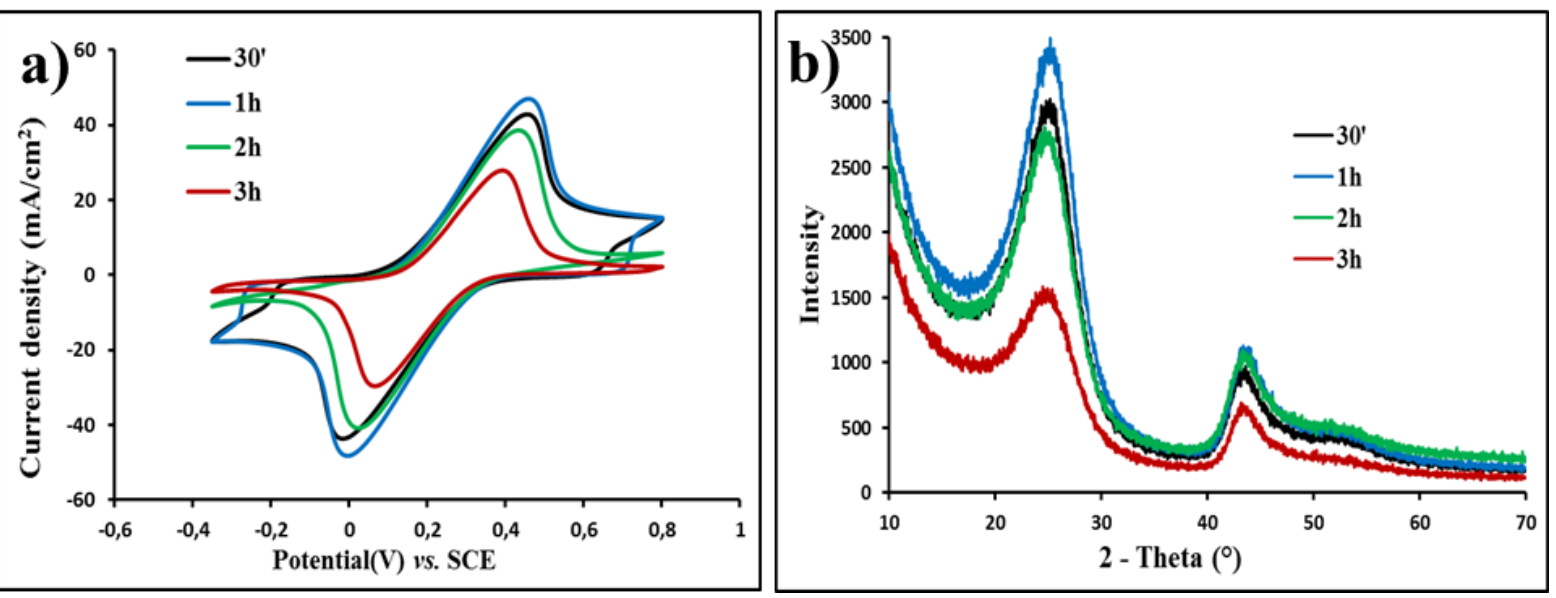

Figure 3. (a) Cyclic voltammograms (CVs) in potassium hexacyanoferrate solution at scan rate 7 $\mathrm{mV} / \mathrm{s}$, and (b) X-ray diffraction patterns of electrodes at different treatment times.

To understand deeply the effect of thermal treatment, various tests were performed under different times at a temperature of $1000^{\circ} \mathrm{C}$ under a nitrogen flow mixing with $1 \%$ oxygen. Peak currents observed on the cyclic voltammograms (CVs) increased with time from 30 min to $1 \mathrm{~h}$ (Figure 3a). Nevertheless, a strong drop was noticed continuously from $2 \mathrm{~h}$ to $3 \mathrm{~h}$ which resulted from the destruction of carbonaceous framework due to the high reaction rate between oxygen and carbon at this temperature. In fact, by increasing the time at $1000^{\circ} \mathrm{C}$, graphitic carbon is also oxidized which induces the decrease of the average crystallite size and the structural demolition. This phenomenon was often observed in studies using thermal treatment $[40,41]$. It could be seen in Figure $3 \mathrm{~b}$, as treatment time was lengthened to $3 \mathrm{~h}$, the average crystallite size declined significantly (Table 2). Simultaneously, the pore system was also demolished, leading to the drop of pore volume to $0.0041 \mathrm{~cm}^{3} / \mathrm{g}$ and pore size was enlarged to $42.2 \AA$ (Table 1 ). Therefore, the choice of a suitable applied treatment temperature or time was important to get both good property and conservation of initial carbonaceous structure. 


\subsection{Mineralization of paracetamol by electro-Fenton reaction}

The prepared cathode was applied to degrade paracetamol (PCM) in acidic aqueous medium by the electro-Fenton $(\mathrm{EF})$ reaction. The mineralization degree of treated solution was monitored by TOC to indicate the efficiency of EF process. As seen on the Figure 5a, the TOC removal rate after $2 \mathrm{~h}$ treatment using $\mathrm{PCF}$ cathode was $31 \%$ higher than on raw $\mathrm{CF}$, proving that the PCF was a promising electrode for the elimination of recalcitrant pharmaceutical pollutants using EF technology. The outstanding performance of PCF could be ascribed to the better hydrophilicity, higher electroactive surface area and crystallinity after thermal treatment. The better crystallization should also contribute to rise conductivity of PCF which encourage faster electron transport in framework for more $\mathrm{H}_{2} \mathrm{O}_{2}$ production from oxygen reduction reaction (ORR) [17]. In fact, the accumulations of $\mathrm{H}_{2} \mathrm{O}_{2}$ on PCF cathode was $24.6 \mathrm{mg} \mathrm{L}^{-1}$, which was nearly 3 times higher than $7.9 \mathrm{mg} \mathrm{L}^{-1}$ on raw $\mathrm{CF}$ after $80 \mathrm{~min}$ (Figure 4a). Experiment degradation was controlled at a constant applied current of $-40 \mathrm{~mA}\left(-20 \mathrm{~mA} / \mathrm{cm}^{2}\right)$. The observed cell voltage was $3.9 \mathrm{~V}$ for PCM instead of $5.3 \mathrm{~V}$ for raw CF definitely because of the carbon fibres resistance decreases. It was noticed that the porous structure also helped dissolved oxygen in electrolyte solution to move easily and quickly to the whole sites of cathode. Abundant amount of hydroxyl radical ( $\left.{ }^{\circ} \mathrm{OH}\right)$ was then generated and used here as oxidizing agent.

In contrast, in the case of bare cathode, because of hydrophobic characteristic, oxygen molecules could less easily move insight the network, so the EF reaction just happened difficultly at the cathode surface. In point of fact, raw CF was still awash while PCF was submerged immediately when contacting with electrolyte solution (Figure 4b). 

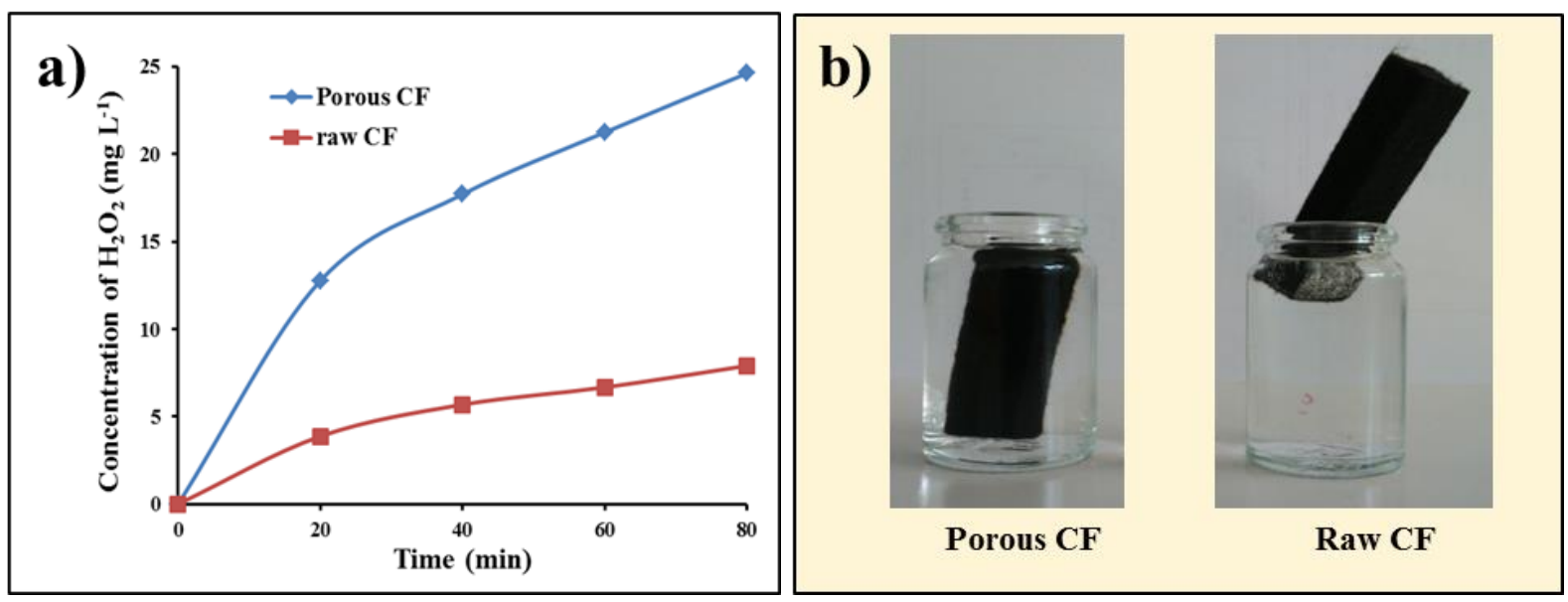

Figure 4. (a) The $\mathrm{H}_{2} \mathrm{O}_{2}$ concentration-time curves of Porous $\mathrm{CF}$ and raw $\mathrm{CF}$ at current density of $-20 \mathrm{~mA} / \mathrm{cm}^{2}, 30 \mathrm{~mL}$ of $\mathrm{Na}_{2} \mathrm{SO}_{4} 50 \mathrm{mM}$, and $\mathrm{pH}=3$, and (b) Image of different cathodes in electrolyte solutions.

The degradation of PCM attained $51 \%$ in $2 \mathrm{~h}$ treatment, and increase slowly due to the formation of the persistent complexes between iron catalyst and carboxylic acids like oxamic acid, oxalic acid coming from the bond cleavage of initial paracetamol molecule. These complexes are very difficult to mineralized by $\bullet \mathrm{OH}$, thus limiting the oxidation ability of $\mathrm{EF}$, as noticed by E. Brillas et al. [42]. The mineralization of PCM was considered as finished after 10h when TOC removal reaches $94 \%$ (Figure 5a). The stability of modified cathode was monitored by cleaning PCF electrode with deionized water and reusing for degradation of PCM under the same conditions. The mineralization ratio on recycling cathode showed a little change after 10 cycles. This very small decrease observed in Figure $5 \mathrm{~b}$ could be attributed to the mislaying of carbon fibers during the washing process. This stable performance proved that PCF is a promising cathode which could be applied in environmental fields to treat wastewater polluted containing Persistent Organic Pollutants (POPs) by EF technology. 

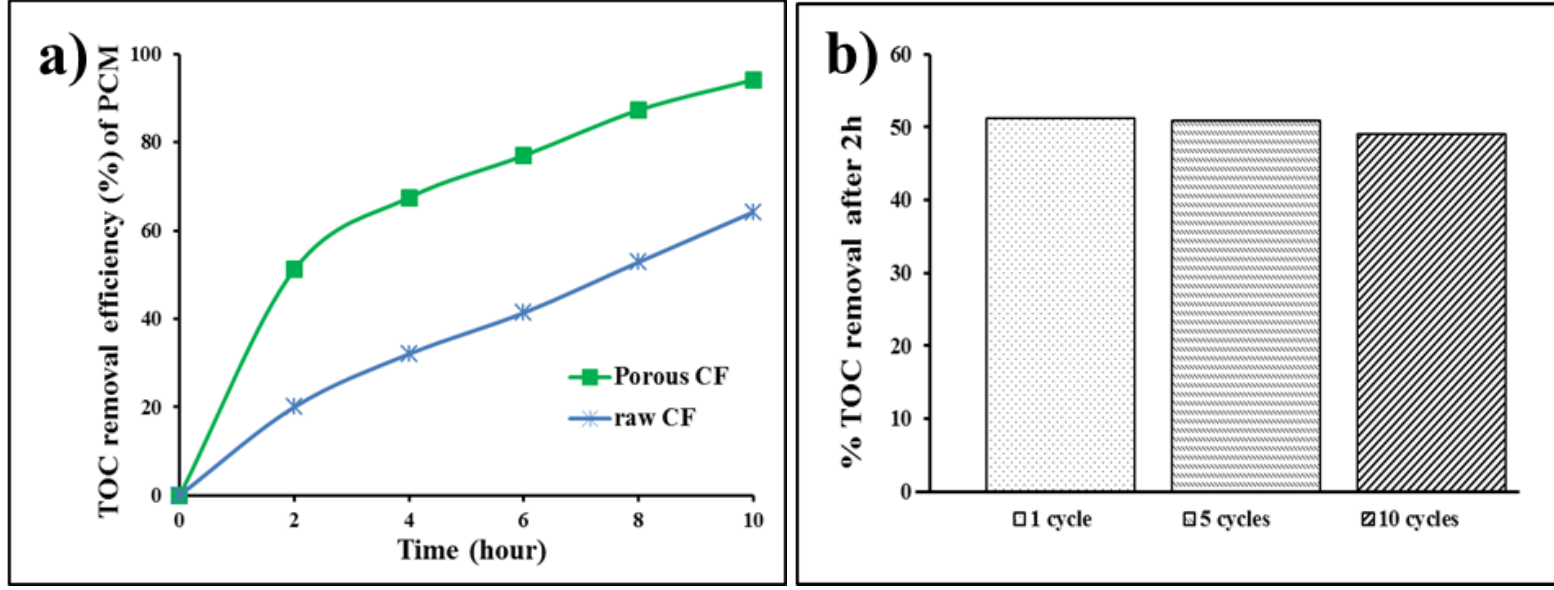

Figure 5. (a) TOC removal efficiency (\%) of PCM on Porous CF and raw CF during $10 \mathrm{~h}$. (b) TOC of PCM removal after $2 \mathrm{~h}$ treatment on PCF during 10 cycles. Conditions: Pt anode; V=30 $\mathrm{mL},[\mathrm{PCM}]=0.1 \mathrm{mM} ;\left[\mathrm{Fe}^{2+}\right]=0.2 \mathrm{mM} ; \mathrm{pH}=3 ;\left[\mathrm{Na}_{2} \mathrm{SO}_{4}\right]=50 \mathrm{mM}$, and $\mathrm{I}=-20 \mathrm{~mA} / \mathrm{cm}^{2}$.

\section{Conclusion}

By using the thermal treatment of carbon felt under gas flow containing $1 \%$ of oxygen in tubular furnace during $1 \mathrm{~h}$ at $1000^{\circ} \mathrm{C}$, a porous carbonaceous material was fabricated due to the selective etching of amorphous carbon. Porous carbon felt (PCF) electrode presented such outstanding properties compared to non-modified one (raw $\mathrm{CF}$ ) like: a surface area 700 times higher, a better hydrophilicity, a higher developed crystallization and an expanded electroactive surface area. The new material proved its significant efficiency once it was applied as cathode in EF process to remove PCM in acidic aqueous medium. The TOC removal was $51 \%$ in $2 \mathrm{~h}$ treatment which was $31 \%$ higher than on raw $\mathrm{CF}$. The value reached $94 \%$ after $10 \mathrm{~h}$ treatment which was a particularly interesting result for a refractory molecule like PCM. Relying on the excellent electrochemical characteristic as well as the stability after 10 cycles, PCF was expected to be used in other promising fields like biofuel cells.

\section{Acknowledgments.}


We gratefully acknowledge financial support from Vietnamese government (VIED -

Vietnam International Education Development - Project 911) and the ANR project

ECOTS/CELECTRON for the partial supplying of materials and chemicals.

\section{REFERENCES}

[1] D. Polat, İ. Balc1, T.A. Özbelge, Catalytic ozonation of an industrial textile wastewater in a heterogeneous continuous reactor, J Environ Chem Eng, 3 (2015) 1860

[2] P. Gong, H. Yuan, P. Zhai, Y. Xue, H. Li, W. Dong, G. Mailhot, Investigation on the degradation of benzophenone-3 by UV/H2O2 in aqueous solution, Chem Eng J, 277 (2015) 97.

[3] H. Zangeneh, A.A.L. Zinatizadeh, M. Habibi, M. Akia, M. Hasnain Isa, Photocatalytic oxidation of organic dyes and pollutants in wastewater using different modified titanium dioxides: A comparative review, J Ind Eng Chem, 26 (2015) 1.

[4] M.A. Rodrigo, N. Oturan, M.A. Oturan, Electrochemically assisted remediation of pesticides in soils and water: a review, Chem Rev, 114 (2014) 8720.

[5] A. Özcan, Y. Şahin, A. Savaş Koparal, M. A. Oturan, Carbon sponge as a new cathode material for the electro-Fenton process: Comparison with carbon felt cathode and application to degradation of synthetic dye basic blue 3 in aqueous medium, J Electroanal Chem, 616 (2008) 71.

[6] C.-T. Wang, W.-L. Chou, M.-H. Chung, Y.-M. Kuo, COD removal from real dyeing wastewater by electro-Fenton technology using an activated carbon fiber cathode, Desalination, 253 (2010) 129.

[7] E. Petrucci, A. Da Pozzo, L. Di Palma, On the ability to electrogenerate hydrogen peroxide and to regenerate ferrous ions of three selected carbon-based cathodes for electro-Fenton processes, Chem Eng J, 283 (2016) 750.

[8] Enric Brillas, Ignasi Sirés, M.A. Oturan, Electro-Fenton Process and Related Electrochemical Technologies Based on Fenton's Reaction Chemistry, Chem Rev, 109 (2009) 6570.

[9] Enrique Brillas, Rosa Maria Bastida, Elisabet Llosa, J. Casado, Electrochemical Destruction of Aniline and 4-Chloroaniline for Wastewater Treatment Using a Carbon-PTFE 02-Fed Cathode, J Electrochem Soc, 142 (1995) 1733.

[10] E. Brillas, J.C. Calpe, J. Casado, Mineralization of 2,4-D by advanced electrochemical oxidation processes, Water Res, 34 (2000) 2253.

[11] C. Badellino, C.A. Rodrigues, R. Bertazzoli, Oxidation of pesticides by in situ electrogenerated hydrogen peroxide: Study for the degradation of 2,4-dichlorophenoxyacetic acid, J Hazard Mater, 137 (2006) 856.

[12] A. Da Pozzo, E. Petrucci, C. Merli, Electrogeneration of hydrogen peroxide in seawater and application to disinfection, J Appl Electrochem, 38 (2008) 997.

[13] L. Zhou, Z. Hu, C. Zhang, Z. Bi, T. Jin, M. Zhou, Electrogeneration of hydrogen peroxide for electro-Fenton system by oxygen reduction using chemically modified graphite felt cathode, Sep Purif Technol, 111 (2013) 131.

[14] T.X.H. Le, M. Bechelany, S. Lacour, N. Oturan, M.A. Oturan, M. Cretin, High removal efficiency of dye pollutants by electron-Fenton process using a graphene based cathode, Carbon, 94 (2015) 1003.

[15] F. Yu, M. Zhou, X. Yu, Cost-effective electro-Fenton using modified graphite felt that dramatically enhanced on $\mathrm{H} 2 \mathrm{O} 2$ electro-generation without external aeration, Electrochim Acta, 163 (2015) 182. 
[16] X. Zhang, J. Fu, Y. Zhang, L. Lei, A nitrogen functionalized carbon nanotube cathode for highly efficient electrocatalytic generation of $\mathrm{H} 2 \mathrm{O} 2$ in Electro-Fenton system, Sep Purif Technol, 64 (2008) 116.

[17] E. Pajootan, M. Arami, M. Rahimdokht, Discoloration of wastewater in a continuous electro-Fenton process using modified graphite electrode with multi-walled carbon nanotubes/surfactant, Sep Purif Technol, 130 (2014) 34.

[18] G. Zhang, F. Yang, M. Gao, X. Fang, L. Liu, Electro-Fenton degradation of azo dye using polypyrrole/anthraquinonedisulphonate composite film modified graphite cathode in acidic aqueous solutions, Electrochim Acta, 53 (2008) 5155.

[19] F.J. García-Mateos, R. Ruiz-Rosas, M.D. Marqués, L.M. Cotoruelo, J. Rodríguez-Mirasol, T. Cordero, Removal of paracetamol on biomass-derived activated carbon: Modeling the fixed bed breakthrough curves using batch adsorption experiments, Chem Eng J, 279 (2015) 18. [20] T. A. Ternes, Occurrence of drugs in german sewage treatment plants and rivers, Water Res, 32 (1998) 3245.

[21] D.W. Kolpin, E.T. Furlong, M.T. Meyer, E.M. Thurman, S.D. Zaugg, L.B. Barber, H.T. Buxton, Pharmaceuticals, Hormones, and Other Organic Wastewater Contaminants in U.S. Streams, 1999 - 2000: A National Reconnaissance, Environ Sci Technol, 36 (2002) 1202. [22] P.H. Roberts, K.V. Thomas, The occurrence of selected pharmaceuticals in wastewater effluent and surface waters of the lower Tyne catchment, Sci Total Environ, 356 (2006) 143. [23] I. Kabdaşli, M. Gürel, O. Tünay, Pollution prevention and waste treatment in chemical synthesis processes for pharmaceutical industry, Water Sci Technol, 39 (1999) 265.

[24] I. Sirés, J.A. Garrido, R. M. Rodríguez, P.L. Cabot, F. Centellas, C. Arias, E. Brillas, Electrochemical Degradation of Paracetamol from Water by Catalytic Action of $\mathrm{Fe}^{2+}, \mathrm{Cu}^{2+}$, and UVA Light on Electrogenerated Hydrogen Peroxide, J Electrochem Soc, 153 (2006) D1. [25] M.D. de Luna, M.L. Veciana, C.C. Su, M.C. Lu, Acetaminophen degradation by electroFenton and photoelectro-Fenton using a double cathode electrochemical cell, J Hazard Mater, 217-218 (2012) 200.

[26] M. Irani, L.R. Rad, H. Pourahmad, I. Haririan, Optimization of the combined adsorption/photo-Fenton method for the simultaneous removal of phenol and paracetamol in a binary system, Microporous and Mesoporous Mater, 206 (2015) 1.

[27] L. Zhang, X. Yin, S.F.Y. Li, Bio-electrochemical degradation of paracetamol in a microbial fuel cell-Fenton system, Chem Eng J, 276 (2015) 185.

[28] A.G. Trovó, S.A.S. Melo, R.F.P. Nogueira, Photodegradation of the pharmaceuticals amoxicillin, bezafibrate and paracetamol by the photo-Fenton process-Application to sewage treatment plant effluent, J Photochem Photobiol, A, 198 (2008) 215.

[29] L.R. Rad, M. Irani, F. divsar, H. Pourahmad, M.S. Sayyafan, I. Haririan, Simultaneous degradation of phenol and paracetamol during photo-Fenton process: Design and optimization, J Taiwan Inst Chem Eng, 47 (2015) 190.

[30] A. Cabrera Reina, L. Santos-Juanes, J.L. García Sánchez, J.L. Casas López, M.I.

Maldonado Rubio, G. Li Puma, J.A. Sánchez Pérez, Modelling the photo-Fenton oxidation of the pharmaceutical paracetamol in water including the effect of photon absorption (VRPA), Appl Catal, B, 166-167 (2015) 295.

[31] A.G. Trovo, R.F. Pupo Nogueira, A. Aguera, A.R. Fernandez-Alba, S. Malato, Paracetamol degradation intermediates and toxicity during photo-Fenton treatment using different iron species, Water Res, 46 (2012) 5374.

[32] A. Abou Chaaya, R. Viter, M. Bechelany, Z. Alute, D. Erts, A. Zalesskaya, K. Kovalevskis, V. Rouessac, V. Smyntyna, P. Miele, Evolution of microstructure and related optical properties of ZnO grown by atomic layer deposition, Beilstein J Nanotechnol, 4 (2013) 690.

[33] A.J. Bard, L.R. Faulkner, Electrochemical Methods: Fundamentals and Applications. , John Wiley and Sons: New York, (2000). 
[34] M. Wen, H. Liu, F. Zhang, Y. Zhu, D. Liu, Y. Tian, Q. Wu, Amorphous FeNiPt nanoparticles with tunable length for electrocatalysis and electrochemical determination of thiols, Chem Commun , (2009) 4530.

[35] L. Zhou, M. Zhou, Z. Hu, Z. Bi, K.G. Serrano, Chemically modified graphite felt as an efficient cathode in electro-Fenton for p-nitrophenol degradation, Electrochim Acta, 140 (2014) 376.

[36] Y. Sheng, S. Song, X. Wang, L. Song, C. Wang, H. Sun, X. Niu, Electrogeneration of hydrogen peroxide on a novel highly effective acetylene black-PTFE cathode with PTFE film, Electrochim Acta, 56 (2011) 8651.

[37] Xiao Yan Zhu, Seung Mi Lee, Young Hee Lee, T. Frauenheim, Adsorption and Desorption of an O2 Molecule on Carbon Nanotubes, Phys Rev Lett, 85 (2000) 2757.

[38] I. Haddadi, S.B. Slema, S.B. Amor, R. Bousbih, A. Bardaoui, W. Dimassi, H. Ezzaouia, Effect of rapid thermal treatment on optical properties of porous silicon surface doped lithium, J Lumin, 160 (2015) 176.

[39] Y. Chai, C.W. Tam, K.P. Beh, F.K. Yam, Z. Hassan, Effects of thermal treatment on the anodic growth of tungsten oxide films, Thin Solid Films, 588 (2015) 44.

[40] Y. Du, R.Z. Chen, J.F. Yao, H.T. Wang, Facile fabrication of porous $\mathrm{ZnO}$ by thermal treatment of zeolitic imidazolate framework-8 and its photocatalytic activity, J Alloys Compd, $551(2013) 125$.

[41] I. Kashif, A.A. Soliman, E.M. Sakr, A. Ratep, XRD and FTIR studies the effect of heat treatment and doping the transition metal oxide on $\mathrm{LiNbO} 3$ and LiNb3O8 nano-crystallite phases in lithium borate glass system, Spectrochim Acta A Mol Biomol Spectrosc, 113 (2013) 15. [42] Enric Brillas, Ignasi Sire’s, M.A. Oturan, Electro-Fenton Process and Related Electrochemical Technologies Based on Fenton's Reaction Chemistry, Chem Rev, 109 (2009) 6570 . 